\title{
Maze and Regression of the Mainstream Culture in the Context
}

\section{of the Multi-cultural Impact}

\author{
Guangbo Mou \\ Dezhou University \\ Dezhou 253000, Shandong, China \\ E-mail: dzwxbgs@163.com
}

\begin{abstract}
This text discusses the five aspects that the mainstream culture has lost itself in the value of the university students in the context of the multi-cultural background. It points out that the maze of the mainstream culture has reached a serious degree. It is a matter of urgency to rescue the mainstream culture and make it revive. This article defines the legal basis of constructing the mainstream culture, the orientation of the construction and the standard of socialist value so that the connotation of the mainstream culture will be more specific and the outline of the mainstream culture will be clearer, as will play an active role in promoting the construction and development of the mainstream culture.
\end{abstract}

Keywords: Multi-culture, Mainstream culture, Maze, Regression

Multi-cultural background refers to a complex of deepening globalization, more frequent exchanges of economy, culture, and thought, fast-developing science and technology, the advent of information technology, competitive economic trends, fiercely violent ideological value, differentiated social stratum and the continuously changing lifestyle.

Nowadays, economic globalization and cultural diversity result in an unprecedented degree of shock and exchanges among different nations. These do not only reflect the fusion between different cultures but also include the conflicts and contradictions among cultures. Affected by the cultural diversity and pluralism of value, the mainstream culture with socialist value as the core, has been suffering a great impact. Chinese University Students have encountered many obstacles in faith or in ideal. The negative influences brought by some decadent and declining ways of life on college students can not be underestimated. Moral disorders, lack of honesty, phenomenon of counterfeit, and fraudulent activities have been further spread. Feudal superstition, heresy, pornography, gambling, drugs and other social evils have risen again. Money worship, hedonism and individual extremism have flourished. The abuse of power and other negative phenomena of corruption can not been completely prohibited. All these have produced great negative impact that can not be ignored on the college students. In addition, some international hostile forces use various means to accelerate the ideological and cultural infiltration to the university students in China. For example, college students show their resentment, misunderstanding, and inimical emotion against the socialist ideals and other educations of the mainstream culture. The overflow of the plural culture has resulted in a severe impact on mainstream culture, which has gradually withdrawn from the value of the college students.

\section{The impact of "extreme individualism" on the value of the college students}

Today, because information has very well developed, it is convenient for the contemporary Chinese college students to learn about the life styles of the foreigners through the Internet, books, magazines and other forms. Furthermore, the extreme individualism embodied in the life styles has produced far-reaching influences on the value and way of life of the college students. College students belong to an independent thinking group. They demand individuation or personality and personal development and hate the constraints from the authority. The Western individualism just can meet their needs. Tired of the authority from the mainstream culture, many students have accepted individualism and regarded it as a bargaining chip against the education of socialist ideals and beliefs. When dealing with the relationship between nation and person, society and person, collective and individual, they turn to a high degree of individual centrism. 


\section{The impact of money worship on the value of the university students}

People's concept of economy has changed a lot. In the Western society, profit is valued more than justice. Personal struggle is stressed too. Especially, successful people are respected for they have made outstanding contributions to the community. All these have produced great impacts on the traditional Chinese concepts, that is, justice is superior to profit and business people are underestimated in society. More students are aware of the importance of economic development and the essentiality of realizing the improvement of their material life. However, being affected by the guiding trend of economic interests, to some degrees, some college students have distorted their understanding of money and material and transferred their life objectives of contributing to the society to the individual's development and the pursuit of wealth. Because of pursuing extreme personal interest, the college students will not pay more attention to the development and progress of the society any more. Indulged in money or material worship, they have lost themselves and can not fulfill their contributions to the society. Social survey showed that in a questionnaire of "what is happiness", $55 \%$ of the students think that happiness means enough money, successful business and harmonious family. And money was put in the first place. Students, in the life planning process, are obviously affected by the thought of money worship. They stress their pursuit of money and material comforts and weaken their insistence of the social contribution.

\section{The impact from the extensive introduction of a variety of Western political thoughts in the wide range on the value of the college students}

Western political thoughts are in flood. Especially, some international hostile forces adopt various means to accelerate the assimilation and erosion to the university students politically and ideologically. Early in New China, they put their hope of peaceful evolution of China on the third and fourth generation, that is to say, the present young people. By now, they have not given up this strategic scheme. By a variety of means, they are imbuing into Chinese students the Western bourgeois political views, value, and way of life in an attempt to achieve their political goals in an imperceptible way. On the contrary, the ideological and political education in China is not optimistic. Some local departments or authorities and school leaders have not attached enough importance to ideological and political education. The resultant force from the whole society of stressing and supporting the ideological and political education has not yet been formed. Ideological and political theory courses in schools are lack of effectiveness. Textbooks of philosophy and other social science disciplines are lagging behind. The ideological and political education is straying away from the students' ideological reality. A small number of schools have not put the ideological and political education in the first place throughout the whole process of teaching. Student management is not in line with the requirements of the situation development. Ideological and political education needs further strengthening. A few teachers can not completely qualify for their posts. Such a negative situation of "strong West and weak China" has seriously affected the shape of the right ideological and political beliefs of college students. It can even shake their confidence of the leadership of the Chinese Communist Party and of Chinese politics.

\section{The unfairness in the social changes and adjustment process has produced impacts on the value of the college students}

College students are concerned with the state and society. However, the phenomenon of some unfairness in the process of social changes and adjustments makes them in great maze. Since the implementation of the reform and opening policy, China has seen a new social class differentiation, the emergence of new private entrepreneurs and the new working class. Social contradictions have accumulated and got prominent. The corruption of some Party members and officials, the social polarization, and the fact that the vulnerable groups are in unfavorable situation of society have produced a serious negative impact on the value of the university students. They have gradually lost the ideal that they have pursued and begun to question the possibility of building a harmonious society. What is more important is that the social injustice reduces their strong sense of identity. Their consciousness about the mainstream culture of devoting themselves to the nation and society is in maze.

\section{The impact of network culture on the value of the university students}

Contemporary college students are living in the era of information explosion. Particularly, the proliferation of Internet culture makes the students get lost in the ocean of information. The appearance of Internet has promoted the communications among people and accelerated the pace of transferring knowledge. However, there are good and bad net cultures. The filthy reality severely affects the formation of the mainstream cultural consciousness of college students. Online games, online chat and love matters, pornographic movies, or even reactionary words, evil crimes, and undesirable information against the governments and other people regardless of social and moral constraints on the network, the superficial cultural activities such as fast-food love, cultural fast food, etc have 
come into being. The mixed and confused activities seriously affected the shape of the healthy ideals and beliefs of college students and resulted in the decline of the college students in mainstream cultural consciousness. China's mainstream culture has been in maze like this. When we ask, "what is the mainstream culture in China today", for the students in the college campus, adults, and those teachers "imparting knowledge and solving the problems" is not an easy thing. Faced with this severe situation, I think that exploring the true meaning of mainstream culture and letting the mainstream culture of China to re-occupy the campus or even the main front of the whole field of social consciousness brooks no delay.

If we want to understand the connotation of the Chinese mainstream culture, we must explore the most fundamental ideological and theoretical foundation of the socialist mainstream culture and make clear what is the nature of China and what is the conduct code of a citizen of the People's Republic of China and what is the core socialist value. Back to the root, we can find that China does have the basis for constructing the socialist mainstream culture. We have named our country as the People's Republic of China and the Constitution clearly states the nature of socialism of China. This is the most fundamental ideological and theoretical foundation for building the socialist mainstream culture. We believe that "Constitution of the People's Republic of China" and "Implementation Program of the Civic Virtue of the People's Republic of China" and Hu Jintao's socialist Concept of Honor and Disgrace can reflect the guiding ideology for constructing the mainstream culture of China.

\section{1 "Constitution of the People's Republic of China” is the fundamental legal basis for the mainstream culture construction}

The first article of the Constitution prescribes that the People's Republic of China is a socialist state of the people's democratic dictatorship led by the working class and based on the alliance of workers and peasants. The socialist system is the basic system of the PRC. Any organizations or individuals are prohibited to destruct the socialist system. The second article is that all power of the People's Republic of China belongs to the people. Article VI is that the basis of the socialist economic system of the People's Republic of China is the socialist public ownership of means of production, namely, the ownership by the whole people and the work masses collectivity ownership. Socialist public ownership system wipes out the exploitation system and carries out the principle of distribution according to work. Article XII stipulates that socialist public property is inviolable. The state protects socialist public property. Any organization or individual must not seize or destroy any state and collective assets by any means.

\subsection{Implementation Outline of Civic Virtue of the People's Republic of China is the direction of the mainstream} culture construction

Implementation Outline regulates that socialist ethics should adhere to taking serving the people as the core, collectivism as the principle, loving China and the people, loving labor, science and socialism as the basic requirements, and social morality, professional ethics and family value as the focal points. During the course of constructing the civic morality, these should be specified and standardized to be the norms of behavior accepted and obeyed by all citizens. Especially, "serving the people, as the core of constructing civic morality" is a significant sign that the socialist moral distinguishes itself from other social forms of morality. "Collectivism as the principle of constructing civic morality" is the necessary requirement of socialist economic, political and cultural development. "Love China and the people, love labor, science and socialism, as the basic requirements of building civic morality" is the legal obligation and moral responsibility that every citizen should bear.

$5.3 \mathrm{Hu}$ Jintao's famous exposition on socialist "honor and shame" reflects the socialist value, that is the "Eight Honors and Eight disgraces"

Love the country, do it no harm. Serve the people, do no disservice. Follow science, discard ignorance. Be diligent, not indolent. Be united, help each other; make no gains at other's expense. Be honest and trustworthy; do not spend ethics for profits. Be disciplined and law-abiding; not chaotic and lawless. Live plainly, struggle hard; do not wallow in luxuries and pleasures.

In today's society where plural culture is flooding arbitrarily and the mainstream culture loses its way, we must in the whole society, especially in the campus vigorously advocate the socialist mainstream culture, set things right, completely know the direction, unify ideas, adhere to Marxism as the guidance, take the common ideal of constructing socialism with Chinese characteristics as the goal, insist on serving the people and adhere to the "Eight Honors and Eight Shames". We should let the mainstream culture re-occupy the socialist positions on campus, and really realize that the dominant culture enters schools, classrooms and affects the minds. 


\section{References}

Fan, Xiaoying and Rao, Wuyuan. (2009). The lack and rebuilding of the university spirit under the impact of the multi-culture. Field of Vision.

Opinion of CPC Central Committee and State Council on Further Strengthening and Improving Ideological and Political Education. August 26, 2004.

Shang, Jieqiang. (2009). Multicultural ideals and beliefs for students in the context of multi-culture. Theory of Learning, Issue 1. 